\title{
Oceanobacillus kapialis sp. nov., from fermented shrimp paste in Thailand
}

Correspondence
Somboon Tanasupawat
Somboon.T@chula.ac.th

The genus Oceanobacillus was first described by Lu et al. (2001) to accommodate an aerobic, rod-shaped, sporeforming, halophilic bacterium, Oceanobacillus iheyensis. At the time of writing, the genus Oceanobacillus comprised: $O$. iheyensis from a deep-sea environment (Lu et al., 2001); Oceanobacillus caeni from wastewater (Nam et al., 2008); Oceanobacillus picturae from a painting (Heyrman et al., 2003; Lee et al., 2006); Oceanobacillus profundus from deep-sea sediment (Kim et al., 2007); Oceanobacillus chironomi from a chironomid egg mass (Raats \& Halpern, 2007); Oceanobacillus oncorhynchi subsp. oncorhynchi from the skin of a rainbow trout (Yumoto et al., 2005); and O. oncorhynchi subsp. incaldanensis from an algal mat (Romano et al., 2006). To date, the numerous reports on halophilic bacteria have revealed novel isolates with distinct properties from various salty environments resulting in a proliferation in the number of genera of moderately halophilic bacteria, including Marinococcus

Abbreviation: DAP, diaminopimelic acid.

The GenBank/EMBL/DDBJ accession number for the 16S rRNA gene sequence of strain SSK2-2 $2^{\top}$ is $A B 366005$.

A table showing the cellular fatty acid compositions of strain SSK2-2 ${ }^{\top}$ and related taxa is available as supplementary material with the online version of this paper.
(Hao et al., 1984), Bacillus (Ventosa et al., 1989), Amphibacillus (Niimura et al., 1990; Zhilina et al., 2001), Halobacillus (Spring et al., 1996), Tetragenococcus (Satomi et al., 1997), Virgibacillus (Heyndrickx et al., 1998), Gracilibacillus (Wainø et al., 1999), Filobacillus (Schlesner et al., 2001), Oceanobacillus (Lu et al., 2001), Lentibacillus (Yoon et al., 2002), Paraliobacillus (Ishikawa et al., 2002), Halolactibacillus (Ishikawa et al., 2005), Cerasibacillus (Nakamura et al., 2004), Pontibacillus (Lim et al., 2005), Tenuibacillus (Ren \& Zhou, 2005a), Salinibacillus (Ren \& Zhou, 2005b), Alkalibacillus (Jeon et al., 2005), Thalassobacillus (García et al., 2005) and Piscibacillus (Tanasupawat et al., 2007). Here, the isolation, phenotypic and chemotaxonomic characteristics, DNA-DNA relatedness and phylogenetic properties of a novel moderately halophilic isolate, designated SSK2 $-2^{\mathrm{T}}$, from fermented shrimp paste (ka-pi), which is fermented mainly from shrimp with a high concentration of $\mathrm{NaCl}(20-30 \%$, w/v) (Phithakpol et al., 1995; Tanasupawat \& Komagata, 2001), are described.

Strain SSK $2-2^{\mathrm{T}}$ was isolated from fermented shrimp paste samples collected from a market in Samutsakorn Province in the central part of Thailand. The spread-plate technique was used on agar plates of Lentibacillus medium [JCM medium no. 377, $\mathrm{pH} 7.2$, composed of $\left(1^{-1}\right): 100 \mathrm{~g} \mathrm{NaCl}$, 
5 g Casamino acids, 5 g yeast extract, 1 g glutamic acid, 2 g $\mathrm{KCl}, 3 \mathrm{~g}$ trisodium citrate, $20 \mathrm{~g} \mathrm{MgSO}_{4} \cdot 7 \mathrm{H}_{2} \mathrm{O}, 36 \mathrm{mg}$ $\mathrm{FeCl}_{2} \cdot 4 \mathrm{H}_{2} \mathrm{O}, \quad 0.36 \mathrm{mg} \quad \mathrm{MnCl}_{2} \cdot 4 \mathrm{H}_{2} \mathrm{O}$ and $20 \mathrm{~g}$ agar] (Namwong et al., 2005), which were incubated at $37{ }^{\circ} \mathrm{C}$ for 7 days. Liquid cultures of strain SSK2-2 ${ }^{\mathrm{T}}$ and $O$. picturae KCTC $3821^{\mathrm{T}}$ were cultivated in Erlenmeyer flasks containing the same medium and incubated on a rotary shaker. Cell shape, cell size, cell arrangement and colony size were examined using cells grown on JCM medium no. 377 agar at $37{ }^{\circ} \mathrm{C}$ for 5 days. The Hucker-Conn modification was used for Gram staining (Hucker \& Conn, 1923). Spore formation was examined on Gram-stained specimens. Critical-point-dried cells were observed under a scanning electron microscope. Flagella were examined as described by Forbes (1981). Physiological and biochemical characteristics were analysed as described by Thornley
(1960), Leifson (1963) and Barrow \& Feltham (1993). Growth under anaerobic conditions on agar plates with or without nitrate $(1 \%, \mathrm{w} / \mathrm{v})$ was investigated using a GasPak (BBL) anaerobic jar. Growth was determined at various temperatures $\left(8-50{ }^{\circ} \mathrm{C}\right), \mathrm{pH}(5.0,6.0,7.0,7.5,8.0,9.0$ and $10.0)$ and $\mathrm{NaCl}$ concentrations $(0-30 \%, w / v)$. At low $\mathrm{NaCl}$ concentrations $(0-2.0 \%, \mathrm{w} / \mathrm{v}), \mathrm{MgSO}_{4} \cdot 7 \mathrm{H}_{2} \mathrm{O}$ and $\mathrm{KCl}$ were omitted from the test medium. Growth was monitored by measuring culture turbidity at $660 \mathrm{~nm}$ (Namwong et al., 2005). Diaminopimelic acid (DAP) type in the peptidoglycan and menaquinones were analysed as described previously (Komagata \& Suzuki, 1987). Polar lipids were determined according to the methods of Minnikin et al. (1984) and Albert et al. (2005). Quantitative analysis of cellular fatty acids was carried out as described previously (Sasser, 1990; Kämpfer \&

Table 1. Differential characteristics of strain SSK2-2 ${ }^{\top}$ (O. kapialis sp. nov.) and strains of Oceanobacillus species

Strains: 1, SSK2-2 ${ }^{\mathrm{T}}$ (data from this study); 2, O. picturae KCTC $3821^{\mathrm{T}}$ (this study, except where marked); 3, O. iheyensis JCM $11309^{\mathrm{T}}$ (Lu et al., 2001); 4, O. oncorhynchi subsp. oncorhynchi JCM $12661^{\mathrm{T}}$ (Yumoto et al., 2005); 5, O. profundus KCCM 42318 ${ }^{\mathrm{T}}$ (Kim et al., 2007); 6, O. caeni KCTC

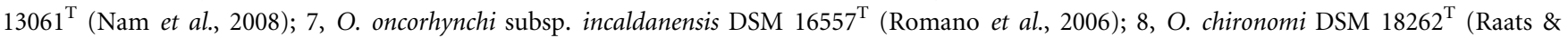
Halpern, 2007). +, Positive; -, negative; w, weak; NA, not available.

\begin{tabular}{|c|c|c|c|c|c|c|c|c|}
\hline Characteristic & 1 & 2 & 3 & 4 & 5 & 6 & 7 & 8 \\
\hline Colony size $(\mathrm{mm})$ & $0.3-2.7$ & $0.1-1.5$ & NA & $2-3$ & NA & NA & NA & NA \\
\hline \multicolumn{9}{|l|}{ Spores ${ }^{\star}$} \\
\hline Position & $\mathrm{T}$ & $\mathrm{T}$ & $\mathrm{T}, \mathrm{S}$ & $S$ & $\mathrm{~T}$ & $\mathrm{C}$ & - & $\mathrm{T}, \mathrm{S}$ \\
\hline $\begin{array}{l}\text { Temperature range for } \\
\text { growth }\left({ }^{\circ} \mathrm{C}\right)\end{array}$ & $8-43$ & $8-40$ & $15-42$ & $15-40$ & $15-42$ & $20-45$ & $10-40$ & $12-46$ \\
\hline \multicolumn{9}{|l|}{$\begin{array}{l}\mathrm{NaCl} \text { concentration for } \\
\text { growth }(\mathrm{w} / \mathrm{v}, \%)\end{array}$} \\
\hline Optimum & $6-14$ & $6-12$ & 3 & 7 & $1-3$ & $2-5$ & 10 & $1-3$ \\
\hline Range & $0.5-24.0$ & $0-22$ & $0-21$ & $0-22$ & $0-14$ & $0-10$ & $5-20$ & $0-11$ \\
\hline \multicolumn{9}{|l|}{ Hydrolysis of: } \\
\hline Aesculin & - & - & + & $+\ddagger$ & + & - & $+\S$ & $w \$$ \\
\hline \multicolumn{9}{|l|}{ Acid from: } \\
\hline L-Arabinose & + & - & - & NA & - & + & NA & NA \\
\hline D-Fructose & + & - & + & + & + & + & NA & NA \\
\hline Glycerol & - & + & + & NA & + & + & NA & NA \\
\hline Maltose & + & - & + & + & + & + & NA & NA \\
\hline D-Mannitol & + & - & $\mathrm{W} \ddagger$ & $-\neq$ & + & $\mathrm{w}$ & NA & NA \\
\hline D-Mannose & + & + & + & + & + & NA & $+\S$ & $-\$$ \\
\hline Melibiose & - & - & -11 & + & - & $\mathrm{w}$ & $\mathrm{NA}$ & NA \\
\hline Methyl $\alpha$-D-glucoside & - & + & NA & NA & NA & NA & NA & $\mathrm{NA}$ \\
\hline Trehalose & - & - & $-\ddagger$ & + & + & NA & NA & NA \\
\hline $\begin{array}{l}\text { DNA G }+C \text { content } \\
(\mathrm{mol} \%)\end{array}$ & 39.7 & $40 \dagger$ & 36 & 38.5 & 40.2 & 33.6 & 40.1 & 38.1 \\
\hline
\end{tabular}

*Abbreviations: E, ellipsoidal; ES, ellipsoidal or spherical endospores; O, oval; C, central; S, subterminal; T, terminal.

$\dagger$ Data from Lee et al. (2006).

\$Data from Kim et al. (2007).

§Data from Nam et al. (2008).

IIData from Romano et al. (2006). 
Kroppenstedt, 1996). DNA was purified as described by Saito \& Miura (1963). The DNA G+C content was determined by using reversed-phase HPLC (Tamaoka \& Komagata, 1984). DNA-DNA hybridization was conducted in microdilution-well plates, as reported by Ezaki et al. (1989), and detected by using the colorimetric method reported by Tanasupawat et al. (2000). The 16S rRNA gene was sequenced as described previously (Seearunruangchai et al., 2004). The determined sequence (1487 bases) was aligned with selected sequences obtained from GenBank/ EMBL/DDBJ by using CLUSTAL_X version 1.83 (Thompson et al., 1997). The alignment was edited manually to remove gaps and ambiguous nucleotides prior to the construction of the phylogenetic tree using the neighbour-joining method (Saitou \& Nei, 1987) in MEGA version 2.1 (Kumar et al., 2001). The confidence values of branches of the phylogenetic tree were determined using bootstrap analyses (Felsenstein, 1985) based on 1000 resamplings.

The phenotypic and chemotaxonomic characteristics of strain SSK2-2 $2^{\mathrm{T}}$, a moderately halophilic, rod-shaped bacterium, were determined. Results are listed in the species description, Table 1 and in Supplementary Table S1 (available in IJSEM Online). Strain SSK2 $-2^{\mathrm{T}}$ produced oval terminal endospores in swollen sporangia (Fig. 1) and contained meso-DAP as the diagnostic diamino acid in the cell-wall peptidoglycan. The predominant isoprenoid quinone was MK-7. The major cellular fatty acids of the strain were anteiso- $\mathrm{C}_{15: 0}(41.2 \%)$ and anteiso- $\mathrm{C}_{17: 0}$ $(31.3 \%)$. The fatty acid profile (see Supplementary Table $\mathrm{S} 1$ available in IJSEM Online) comprised $\mathrm{C}_{14: 0}(0.7 \%)$, $\mathrm{C}_{16: 0}(3.9 \%), \mathrm{C}_{16: 1} \omega 7 \mathrm{c}$ alcohol $(0.5 \%)$, iso- $\mathrm{C}_{14: 0}(3.8 \%)$, iso- $\mathrm{C}_{15: 0}(1.4 \%)$, iso- $\mathrm{C}_{16: 0}(14.3 \%)$, iso- $\mathrm{C}_{17: 0}(0.8 \%)$ and trace amounts of various summed features. The fatty acid profile was the same as that of O. picturae KCTC $3821^{\mathrm{T}}$; however, the amounts of $\mathrm{C}_{16: 0}$, iso- $\mathrm{C}_{14: 0}$, iso- $\mathrm{C}_{15: 0}$, iso$\mathrm{C}_{16: 0}$ and anteiso- $\mathrm{C}_{17: 0}$ were different from those observed in O. iheyensis KCTC $3954^{\mathrm{T}}$ and O. oncorhynchi subsp. oncorhynchi JCM $12661^{\mathrm{T}}$ as reported by Lee et al. (2006). The difference in the amounts of fatty acids may be due to

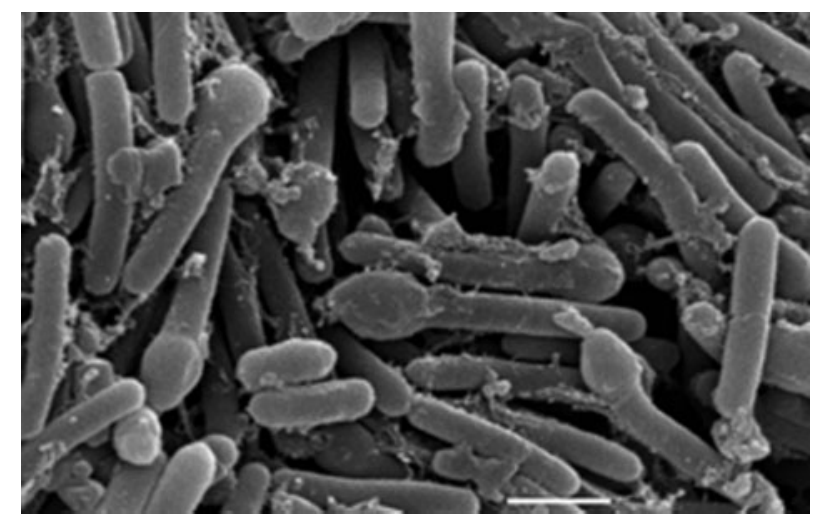

Fig. 1. Scanning electron micrograph of cells of strain SSK2-2 ${ }^{\top}$ grown on JCM medium no. 377 at $37{ }^{\circ} \mathrm{C}$. Bar, $1 \mu \mathrm{m}$. the difference in $\mathrm{NaCl}$ concentration $(0-10 \%, \mathrm{w} / \mathrm{v}, \mathrm{NaCl})$ in the culture medium as reported by Valderrama et al. (1998). Polar lipid analysis revealed the presence of phosphatidylglycerol, diphosphatidylglycerol, an unidentified phospholipid and two unidentified glycolipids. The DNA G + C content was $39.7 \mathrm{~mol} \%$. Phenotypic and chemotaxonomic characteristics of strain SSK2-2 ${ }^{\mathrm{T}}$ were as described in the genus description (Heyrman et al., 2003; Lee et al., 2006) and, based on the $16 \mathrm{~S}$ rRNA gene sequence analysis, it was included in a monophyletic cluster consisting of strains of Oceanobacillus species as shown in Fig. 2. The 16S rRNA gene sequence similarity values between strain SSK2 $22^{\mathrm{T}}$ and O. picturae KCTC $3821^{\mathrm{T}}$, O. profundus KCCM $42318^{\mathrm{T}}$, O. iheyensis KCTC $3954^{\mathrm{T}}$, O. oncorhynchi subsp. oncorhynchi JCM $12661^{\mathrm{T}}$, O. oncorhynchi subsp. incaldanensis DSM $16557^{\mathrm{T}}$, O. caeni KCTC $13061^{\mathrm{T}}$ and O. chironomi DSM $18262^{\mathrm{T}}$ were $98.7,96.2,95.1,95.0,94.5,94.2$ and $93.1 \%$, respectively (Kim et al., 2007; Lee et al., 2006; Lu et al., 2001; Romano et al., 2006; Yumoto et al., 2005; Nam et al., 2008). Furthermore, DNA-DNA hybridization analysis revealed that strain SSK2-2 $2^{\mathrm{T}}$ showed low DNA-DNA relatedness with O. picturae KCTC $3821^{\mathrm{T}}(22.4 \%)$; in the reciprocal analysis, the relatedness between $O$. picturae KCTC $3821^{\mathrm{T}}$ and strain SSK2-2 $2^{\mathrm{T}}$ was $24.9 \%$, indicating that strain SSK2-2 ${ }^{\mathrm{T}}$ was unrelated to O. picturae KCTC $3821^{\mathrm{T}}$ (Wayne et al., 1987). On the basis of its colony size, growth temperature, $\mathrm{pH}$ range, $\mathrm{NaCl}$ tolerance, ability to hydrolyse aesculin, casein and gelatin, ability to produce acid from L-arabinose, Dfructose, glycerol, maltose, D-mannitol, D-mannose and methyl $\alpha$-D-glucoside, DNA G + C content and DNA-DNA relatedness values, strain $\mathrm{SSK} 2-2^{\mathrm{T}}$ can be distinguished from O. picturae KCTC $3821^{\mathrm{T}}$. Therefore, strain SSK2-2 ${ }^{\mathrm{T}}$ represents a novel species in the genus Oceanobacillus, for which the name Oceanobacillus kapialis sp. nov. is proposed.

\section{Description of Oceanobacillus kapialis sp. nov.}

Oceanobacillus kapialis (ka.pi.a'lis. Korean n. ka-pi shrimp paste; N.L. n. kapium shrimp paste; L. suff. -alis adjectival suffix meaning pertaining to; N.L. masc. adj. kapialis pertaining to shrimp paste, the source of isolation).

Cells are Gram-positive, strictly aerobic rods, approximately $0.4-0.5 \times 0.8-3.0 \mu \mathrm{m}$. Oval endospores are formed terminally in swollen sporangia. Motile by means of peritrichous flagella. Colonies are low convex, smooth, circular and white to cream $(0.3-2.7 \mathrm{~mm}$ in diameter). Growth occurs at $8-43{ }^{\circ} \mathrm{C}$ (optimum, $37{ }^{\circ} \mathrm{C}$ ), between $\mathrm{pH} 6$ and 9 (optimum, $\mathrm{pH} 8.0$ ), and in $0.5-24.0 \%(\mathrm{w} / \mathrm{v})$ $\mathrm{NaCl}$ (optimum, 6-14\% NaCl). Anaerobic growth is not observed in the presence of $1 \%(\mathrm{w} / \mathrm{v})$ nitrate. Positive for catalase and oxidase activities and hydrolysis of gelatin and casein, but negative for nitrate reduction, urease, DNase, and hydrolysis of aesculin, Tween 80, tyrosine, starch, xanthine and hypoxanthine. Produces acid from Larabinose, D-fructose, D-glucose, D-mannitol, D-mannose and maltose, but not from amygdalin, cellobiose, aesculin, D-gluconic acid, glycerol, D-galactose, myo-inositol, inulin, lactose, melibiose, melezitose, methyl $\alpha$-D-glucoside, raffi- 


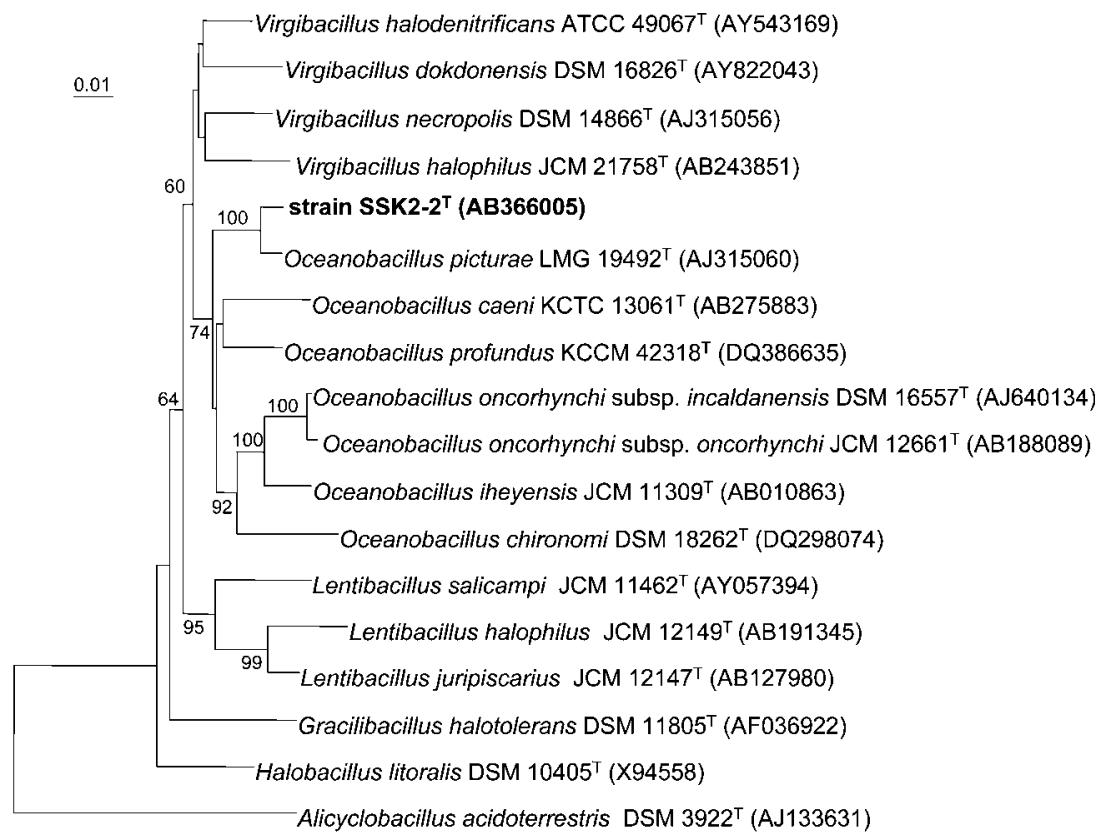

Fig. 2. Phylogenetic tree based on $16 \mathrm{~S}$ rRNA gene sequences showing the relationship between strain SSK $2-2^{\top}$ and strains of related bacterial species. The branching pattern was generated by the neighbour-joining method. Bootstrap values above $60 \%$, based on 1000 replications, are shown at the nodes. Bar, 0.01 substitutions per nucleotide position. nose, D-ribose, L-rhamnose, salicin, D-sorbitol, sucrose, trehalose or D-xylose. The diagnostic diamino acid in the cell-wall peptidoglycan is meso-DAP. MK-7 is the major menaquinone. The predominant fatty acids are anteiso$\mathrm{C}_{15: 0}$ and anteiso- $\mathrm{C}_{17: 0}$. Contains phosphatidylglycerol, diphosphatidylglycerol, an unidentified phospholipid and two unidentified glycolipids.

The type strain is $\mathrm{SSK} 2-2^{\mathrm{T}} \quad\left(=\mathrm{KCTC} \quad 13177^{\mathrm{T}}=\mathrm{PCU}\right.$ $300^{\mathrm{T}}=$ TISTR $1858^{\mathrm{T}}$ ), isolated from fermented shrimp paste (ka-pi) produced in Thailand. The DNA G+C content of the type strain is $39.7 \mathrm{~mol} \%$.

\section{Acknowledgements}

The research grant from the Thailand Research Fund for S. N. (2007) and a grant from KRIBB Research Initiative Program are gratefully acknowledged.

\section{References}

Albert, R. A., Archambault, J., Rosselló-Mora, R., Tindall, B. J. \& Matheny, M. (2005). Bacillus acidicola sp. nov., a novel mesophilic, acidophilic species isolated from acidic Sphagnum peat bogs in Wisconsin. Int J Syst Evol Microbiol 55, 2125-2130.

Barrow, G. I. \& Feltham, R. K. A. (1993). Cowan and Steel's Manual for the Identification of Medical Bacteria, 3rd edn. Cambridge: Cambridge University Press.

Ezaki, T., Hashimoto, Y. \& Yabuuchi, E. (1989). Fluorometric deoxyribonucleic acid-deoxyribonucleic acid hybridization in microdilution wells as an alternative to membrane filter hybridization in which radioisotopes are used to determine genetic relatedness among bacterial strains. Int J Syst Bacteriol 39, 224-229.

Felsenstein, J. (1985). Confidence limits on phylogenies: an approach using the bootstrap. Evolution 39, 783-791.
Forbes, L. (1981). Rapid flagella stain. J Clin Microbiol 13, 807-809. Garcia, M. T., Gallego, V., Ventosa, A. \& Mellado, E. (2005). Thalassobacillus devorans gen. nov., sp. nov., a moderately halophilic, phenol-degrading, Gram-positive bacterium. Int J Syst Evol Microbiol 55, 1789-1795.

Hao, M. V., Kocur, M. \& Komagata, K. (1984). Marinococcus gen. nov., a new genus for motile cocci with meso-diaminopimelic acid in the cell wall; and Marinococcus albus sp. nov. and Marinococcus halophilus (Novitsky and Kushner) comb. nov. J Gen Appl Microbiol 30, 449459.

Heyndrickx, M., Lebbe, L., Kersters, K., De Vos, P., Forsyth, G. \& Logan, N. A. (1998). Virgibacillus: a new genus to accommodate Bacillus panthothenticus (Proom and Knight 1950). Emended description of Virgibacillus panthothenticus. Int J Syst Bacteriol 48, 99-106.

Heyrman, J., Logan, N. A., Busse, H.-J., Balcaen, A., Lebbe, L., Rodriguez-Diaz, M., Swings, J. \& De Vos, P. (2003). Virgibacillus carmonensis sp. nov., Virgibacillus necropolis sp. nov. and Virgibacillus picturae sp. nov., three novel species isolated from deteriorated mural paintings, transfer of the species of the genus Salibacillus to Virgibacillus, as Virgibacillus marismortui comb. nov. and Virgibacillus salexigens comb. nov., and emended description of the genus Virgibacillus. Int J Syst Evol Microbiol 53, 501-511.

Hucker, G. J. \& Conn, H. J. (1923). Method of Gram staining. NY State Agric Exp Stn Tech Bull 93, 3-37.

Ishikawa, M., Ishizaki, S., Yamamoto, Y. \& Yamasato, K. (2002). Paraliobacillus ryukyuensis gen. nov., sp. nov., a new Gram-positive, slightly halophilic, extremely halotolerant, facultative anaerobe isolated from a decomposing marine alga. J Gen Appl Microbiol 48, 269-279.

Ishikawa, M., Nakajima, K., Itamiya, Y., Furukawa, S., Yamamoto, Y. \& Yamasato, K. (2005). Halolactibacillus halophilus gen. nov., sp. nov. and Halolactibacillus miurensis sp. nov., halophilic and alkaliphilic marine lactic acid bacteria constituting a phylogenetic lineage in Bacillus rRNA group 1. Int J Syst Evol Microbiol 55, 2427-2439.

Jeon, C. O., Lim, J.-M., Lee, J.-M., Xu, L.-H., Jiang, C.-L. \& Kim, C.-J. (2005). Reclassification of Bacillus haloalkaliphilus Fritze 1996 as 
Alkalibacillus haloalkaliphilus gen. nov., comb. nov. and the description of Alkalibacillus salilacus sp. nov., a novel halophilic bacterium isolated from a salt lake in China. Int J Syst Evol Microbiol 55, 1891-1896.

Kämpfer, P. \& Kroppenstedt, R. M. (1996). Numerical analysis of fatty acid patterns of coryneform bacteria and related taxa. Can J Microbiol 42, 989-1005.

Kim, Y. G., Choi, D. H., Hyun, S. \& Cho, B. C. (2007). Oceanobacillus profundus sp. nov., isolated from a deep-sea sediment core. Int J Syst Evol Microbiol 57, 409-413.

Komagata, K. \& Suzuki, K. (1987). Lipid and cell-wall analysis in bacterial systematics. Methods Microbiol 19, 161-207.

Kumar, S., Tamura, K., Jakobsen, I. B. \& Nei, M. (2001). MEGA2: molecular evolutionary genetics analysis software. Bioinformatics 17, $1244-1245$.

Lee, J.-S., Lim, J.-M., Lee, K. C., Lee, J.-C., Park, Y.-H. \& Kim, C.-J. (2006). Virgibacillus koreensis sp. nov., a novel bacterium from a salt field, and transfer of Virgibacillus picturae to the genus Oceanobacillus as Oceanobacillus picturae comb. nov. with emended descriptions. Int J Syst Evol Microbiol 56, 251-257.

Leifson, E. (1963). Determination of carbohydrate metabolism of marine bacteria. J Bacteriol 85, 1183-1184.

Lim, J.-M., Jeon, C. O., Song, S. M. \& Kim, C.-J. (2005). Pontibacillus chungwhensis gen. nov., sp. nov., a moderately halophilic Grampositive bacterium from a solar saltern in Korea. Int J Syst Evol Microbiol 55, 165-170.

Lu, J., Nogi, Y. \& Takami, H. (2001). Oceanobacillus iheyensis gen. nov., sp. nov., a deep-sea extremely halotolerant and alkaliphilic species isolated from a depth of $1050 \mathrm{~m}$ on the Iheya Ridge. FEMS Microbiol Lett 205, 291-297.

Minnikin, D. E., O'Donnell, A. G., Goodfellow, M., Alderson, G., Athalye, M., Schaal, A. \& Parlett, J. H. (1984). An integrated procedure for the extraction of bacterial isoprenoid quinones and polar lipids. J Microbiol Methods 2, 233-241.

Nakamura, K., Haruta, S., Ueno, S., Ishii, M., Yokota, A. \& Igarashi, Y. (2004). Cerasibacillus quisquiliarum gen. nov., sp. nov., isolated from a semi-continuous decomposing system of kitchen refuse. Int J Syst Evol Microbiol 54, 1063-1069.

Nam, J.-H., Bae, W. \& Lee, D.-H. (2008). Oceanobacillus caeni sp. nov., isolated from a Bacillus-dominated wastewater treatment system in Korea. Int J Syst Evol Microbiol 58, 1109-1113.

Namwong, S., Tanasupawat, S., Smitinont, T., Visessanguan, W., Kudo, T. \& Itoh, T. (2005). Isolation of Lentibacillus salicampi strains and Lentibacillus juripiscarius sp. nov. from fish sauce in Thailand. Int J Syst Evol Microbiol 55, 315-320.

Niimura, Y., Koh, E., Yanagida, F., Suzuki, K.-I., Komagata, K. \& Kozaki, M. (1990). Amphibacillus xylanus gen. nov., sp. nov., a facultatively anaerobic sporeforming xylan-digesting bacterium which lacks cytochrome, quinone, and catalase. Int J Syst Bacteriol 40, 297-301.

Phithakpol, B., Varanyanond, W., Reungmaneepaitoon, S. \& Wood, H. (1995). The Traditional Fermented Foods of Thailand. Kuala Lumpur: ASEAN Food Handling Bureau Level 3.

Raats, D. \& Halpern, M. (2007). Oceanobacillus chironomi sp. nov., a halotolerant and facultatively alkaliphilic species isolated from a chironomid egg mass. Int J Syst Evol Microbiol 57, 255-259.

Ren, P.-G. \& Zhou, P.-J. (2005a). Tenuibacillus multivorans gen. nov., sp. nov., a moderately halophilic bacterium isolated from saline soil in Xin-Jiang, China. Int J Syst Evol Microbiol 55, 95-99.

Ren, P.-G. \& Zhou, P.-J. (2005b). Salinibacillus aidingensis gen. nov., sp. nov. and Salinibacillus kushneri sp. nov., moderately halophilic bacteria isolated from a neutral saline lake in Xin-Jiang, China. Int $J$ Syst Evol Microbiol 55, 949-953.

Romano, I., Lama, L., Nicolaus, B., Poli, A., Gambacorta, A. \& Giordano, A. (2006). Oceanobacillus oncorhynchi subsp. incaldanensis subsp. nov., an alkalitolerant halophile isolated from an algal mat collected from a sulfurous spring in Campania (Italy), and emended description of Oceanobacillus oncorhynchi. Int J Syst Evol Microbiol 56, 805-810.

Saito, H. \& Miura, K. I. (1963). Preparation of transforming deoxyribonucleic acid by phenol treatment. Biochim Biophys Acta 72, 619-629.

Saitou, N. \& Nei, M. (1987). The neighbor-joining method: a new method for reconstructing phylogenetic trees. Mol Biol Evol 4, 406425.

Sasser, M. (1990). Identification of bacteria by gas chromatography of cellular fatty acids, MIDI Technical Note 101. Newark, DE: MIDI Inc.

Satomi, M., Kimura, B., Mizoi, M., Sato, T. \& Fujii, T. (1997). Tetragenococcus muriaticus sp. nov., a new moderately halophilic lactic acid bacterium isolated from fermented squid liver sauce. Int $J$ Syst Bacteriol 47, 832-836.

Schlesner, H., Lawson, P. A., Collins, M. D., Weiss, N., Wehmeyer, U., Völker, H. \& Thomm, M. (2001). Filobacillus milensis gen. nov., sp. nov., a new halophilic spore-forming bacterium with Orn-D-Glu-type peptidoglycan. Int J Syst Evol Microbiol 51, 425-431.

Seearunruangchai, A., Tanasupawat, S., Keeratipibul, S., Thawai, C., Itoh, T. \& Yamada, Y. (2004). Identification of acetic acid bacteria isolated from fruits collected in Thailand. J Gen Appl Microbiol 50, $47-53$.

Spring, S., Ludwig, W., Marquez, M. C., Ventosa, A. \& Schleifer, K.-H. (1996). Halobacillus gen. nov., with descriptions of Halobacillus litoralis sp. nov. and Halobacillus trueperi sp. nov., and transfer of Sporosarcina halophila to Halobacillus halophilus comb. nov. Int J Syst Bacteriol 46, 492-496.

Tamaoka, J. \& Komagata, K. (1984). Determination of DNA base composition by reversed-phase high-performance liquid chromatography. FEMS Microbiol Lett 25, 125-128.

Tanasupawat, S. \& Komagata, K. (2001). Lactic acid bacteria in fermented foods in Southeast Asia. In Microbial Diversity in Asia. Technology and Prospects, pp. 43-59. Edited by B. H. Nga, H. M. Tan \& K. Suzuki. Singapore: World Scientific Publishing.

Tanasupawat, S., Shida, O., Okada, S. \& Komagata, K. (2000). Lactobacillus acidipiscis sp. nov. and Weissella thailandensis sp. nov., isolated from fermented fish in Thailand. Int J Syst Evol Microbiol 50, 1479-1485.

Tanasupawat, S., Namwong, S., Kudo, T. \& Itoh, T. (2007). Piscibacillus salipiscarius gen. nov., sp. nov., a moderately halophilic bacterium from fermented fish (pla-ra) in Thailand. Int J Syst Evol Microbiol 57, 1413-1417.

Thompson, J. D., Gibson, T. J., Plewniak, F., Jeanmougin, F. \& Higgins, D. G. (1997). The CLUSTAL_X windows interface: flexible strategies for multiple sequence alignment aided by quality analysis tools. Nucleic Acids Res 25, 4876-4882.

Thornley, M. J. (1960). The differentiation of Pseudomonas from other Gram-negative bacteria on the basis of arginine metabolism. J Appl Bacteriol 23, 37-52.

Valderrama, M. J., Monteoliva-Sanchez, M., Quesada, E. \& RamosCormenzana, A. (1998). Influence of salt concentration on the cellular fatty acid composition of the moderately halophilic bacterium Halomonas salina. Res Microbiol 149, 675-679.

Ventosa, A., Garcia, M. T., Kamekura, M., Onishi, H. \& RuizBerraquero, F. (1989). Bacillus halophilus sp. nov., a moderately halophilic Bacillus species. Syst Appl Microbiol 12, 162-166. 
Wainø, M., Tindall, B. J., Schumann, P. \& Ingvorsen, K. (1999). Gracilibacillus gen. nov., with description of Gracilibacillus halotolerans gen. nov., sp. nov.; transfer of Bacillus dipsosauri to Gracilibacillus dipsosauri comb. nov., and Bacillus salexigens to the genus Salibacillus gen. nov., as Salibacillus salexigens comb. nov. Int J Syst Bacteriol 49, 821-831.

Wayne, L. G., Brenner, D. J., Colwell, R. R., Grimont, P. A. D., Kandler, O., Krichevsky, M. I., Moore, L. H., Moore, W. E. C., Murray, R. G. E. \& other authors (1987). International Committee on Systematic Bacteriology. Report of the ad hoc committee on the reconciliation of approaches to bacterial systematics. Int J Syst Bacteriol 37, 463-464.

Yoon, J.-H., Kang, K. H. \& Park, Y.-H. (2002). Lentibacillus salicampi gen. nov., sp. nov., a moderately halophilic bacterium isolated from a salt field in Korea. Int J Syst Evol Microbiol 52, $2043-$ 2048.

Yumoto, I., Hirota, K., Nodasaka, Y. \& Nakajima, K. (2005). Oceanobacillus oncorhynchi sp. nov., a halotolerant obligate alkaliphile isolated from the skin of a rainbow trout (Oncorhynchus mykiss), and emended description of the genus Oceanobacillus. Int J Syst Evol Microbiol 55, 1521-1524.

Zhilina, T. N., Garnova, E. S., Tourova, T. P., Kostrikina, N. A. \& Zavarzin, G. A. (2001). Amphibacillus fermentum sp. nov. and Amphibacillus tropicus sp. nov., new alkaliphilic, facultatively anaerobic, saccharolytic bacilli from Lake Magadi. Microbiology 70, 711-722 (English translation of Mikrobiologiia). 